\title{
Differences in Levels of Autonomy and Fitness of Elementary School Students Based on Transportation Mode
}

\author{
Muhammad Abdul Aziz Santoso ${ }^{1}$, Ali Maksum ${ }^{2}$, Made Pramono ${ }^{3}$ \\ 1.2,3Magister Program of Sport Education, Universitas Negeri Surabaya, Indonesia \\ Email: azizsn7@gmail.com
}

\begin{abstract}
It is known that in addition to biking and walking, many students who prefer to be taken by parents or use an online motorcycle taxi to go to school. Generally, going to school using a bicycle is an alternative means of transportation that is preferred, but because of the lack of parking lots of students who ultimately prefer to be picked up and dropped off. In addition, parenting parents who are too protective of children to require children to be picked up when going to school also indirectly have an unfavorable impact on the child's level of fitness and independence. Whereas for elementary school children, the level of fitness and independence are things that must be developed for their future survival. Children must understand the importance of physical activity and implement it in their lives. For example, children who go to school, they must be more able to think about how to move their body to get to school rather than just relying on the transfer of parents. By walking to school, will increase physical activity of children. Therefore, researchers are then interested in conducting further research. The results of this study are that there are significant differences in the fitness variable of transportation used with a significance level of 0,000 and an F value of 21,914 with a mean difference of 73,393. Walking is the most dominant factor to improve fitness compared to cycling and parents take a motorbike ride to and from school. As for the independence variable there is no significant difference in the mode of transportation used with a significance value of 0.414 with an F value of 0.890 . The conclusion of the research is the use of modes of transportation to the right school can increase children's fitness. Walking is the best transportation to improve fitness then followed by cycling and parents take a ride on a motorcycle. However, to increase a significant independence, it is still not possible to use transportation mode selection because parental care is the determining factor for children's independence other than the education system in schools and the surrounding environment.

Keywords: transportation; independence; fitness
\end{abstract}

\section{Introduction}

Physical fitness indispensable by humans, because these factors strongly support the result of activities undertaken. Physical fitness can be interpreted as the ability and ability of the body when doing a job optimally and efficiently. (Abdurrahim and Hariadi, 2018).

García et.al. (2014) suggested that physical fitness is an integrated measure of all functions (psycho- neurological, musculoskeletal, cardio-respiratory, blood-circulatory and endocrine-metabolic) and structures involved in individual physical activity. Sastaman, (2015) explains "defining physical fitness as the ability to carry out daily activities with full strength and alertness without experiencing significant exhaustion and still having enough energy to do other activities and in dealing with emergency situations".

The level of physical fitness of a person will affect the physical and mind readiness to be able to accept the workload. This also applies to school students, students with a good level of physical fitness will be able to do their learning activities well (Abdurrahim 
and Hariadi, 2018). Furthermore Sholihin and Wahyuni (2013) explained that generally the level of physical fitness of students differed, viewed from how active or not the student.

Independence in the psychological and mentalist sense implies a state of a person in his life who can decide or do something without the help of others (Sa'diyah, 2017). In his psychosocial development theory, Erikson divides his development into four stages, one of which is the Autonomy stage (Komala, 2015). In this stage, it is known that a sign of children's independence can be seen from the child's freedom to do things according to his own way. (Komala, 2015). And provide opportunities to do their own work without being influenced by others and away from shame.

Independence when viewed from a psychological perspective, basically starts from a sense of independence or one's perception of how well individuals can handle a problem that arises. This independence will not appear suddenly but needs to be trained and requires a long process by creating a conducive atmosphere that allows children to develop such independence. Thus, the independence that will be achieved is not only independent in the narrow sense, but also in a broad sense, namely how children experience and carry out social activities on their own (Sa'diyah, 2017).

At present, it is known that in addition to biking and walking, many students prefer to be taken by parents or use an online motorcycle taxi to go to school. Generally, going to school using a bicycle is an alternative means of transportation that is preferred, but because of the lack of parking lots of students who ultimately prefer to be picked up and dropped off. In addition, parenting parents who are too protective of children to require children to be picked up when going to school also indirectly have an unfavorable impact on the child's level of fitness and independence. Whereas for elementary school children, the level of fitness and independence are things that must be developed for their future survival.

Given, one's fitness will affect the physical and mind readiness to be able to accept workloads, in this case students with a good level of physical fitness will be able to do work or activities in terms of smooth learning and not easily tired of learning (Abdurrahim and Hariadi, 2018) . In further development, independence must be had given that humans can not only rely on the help of others. Children must be required to be independent as a process of preparing themselves to face the challenges of the times. So at this time every individual is required to be independent in carrying out every action (Sa'diyah, 2017).

Knowing the importance of developing proper physical fitness and independence conditions. For this reason, the purpose of this study is to analyze the differences between how to use transportation to school and the independence and fitness of students. Some research related to this matter is known to have been done before. Agustavian and Hartati's research (2013) shows the results that the level of physical fitness measured on the MFT test of students walking to school is higher than students cycling to school with a percentage value of $6.9 \%$. Furthermore, Sastaman's research results. (2015) shows that the level of physical fitness of students who walk to school is better than students who cycle to school.

Parenting parents towards their children also contribute to the development of the child itself, especially regarding the child's independence or even the child's fitness. This is in line expressed by Erkelenz (2014) parents play an important role in preventing child obesity. Parents greatly influence the physical activity of their children, for example parents who always spoil their children and are afraid of releasing their children to go to school alone, or 
parents who always spoil their children without providing learning about a process. from parenting as above it is possible to form a child who will always expect help from others or in other words children who always want help.

Children must understand the importance of physical activity and implement it in their lives. For example children who go to school, they should be more able to think about how to move their body to get to school rather than just relying on the transfer of parents, but the problem is when children go to school on a bicycle while school parking facilities are inadequate. The phenomenon of the number of bicycles that are on the school yard is very disturbing with the availability of a narrow parking lot, so that it interferes with the child's own movement activities at school. The solution offered is to change the mode of transportation of children, namely cycling when going to school on foot, however children still choose to walk to school rather than biking. By walking to school, it will increase the physical activity of children without having to sacrifice physical activity caused by the reduction in children's play areas because of the many bikes that are on the school grounds. The point is that if a child goes biking to school, this can increase his physical activity when leaving but causes problems at school because of the limited parking space that can limit the child's space for movement. But if children walk to school, they can increase their physical activity when going to school and do not disturb their space in the school yard because there are not many bikes parked in the yard. But children who choose to walk are still very few. Therefore, researchers are then interested in conducting further research related to the mode of transportation of children going to school by linking children's independence and fitness. The title of this research is "Differences in the Level of Independence and Fitness of Elementary School Students Based on Modes of Transportation".

\section{Research Methods}

The type of research approach used is quantitative. The quantitative approach in research is characterized by, among others, theory / hypothesis testing and the use of standardized test instruments (Maksum, 2018: 14). Non-experimental quantitative approach is used because researchers do not have the opportunity to provide treatment and data processing used in this study using statistical tests. In this study there are two variables, namely independent and dependent. The independent variable is 1, namely the type of student transportation to school, while the dependent variable is 2, namely independence and fitness. The subjects in this study were all students of the 5th grade Kendangsari Public Elementary School as many as 112 students.

The instruments of this study used tests and questionnaires. The test is used to determine student fitness. The instrument uses MFT ( multistage fitness test). while the questionnaire was used to determine the level of student independence. The questionnaire used was taken from Mulyati's research in 2018. The analysis in this study used Manova, which tested the differences of several dependent variables on several independent variables (Maksum, 2018: 118). The Manova test is used to determine differences between groups involving several dependent variables (Sutrisno, 2018). With the provisions of the significance level $<0.05$, the null hypothesis is rejected and if the significance is $>0.05$, then the null hypothesis is accepted. 


\section{Discussion}

The results of this study are to illustrate data on differences in the level of independence and fitness based on modes of transportation to and from Kendangsari I Public Elementary School Surabaya. Data collection in this study consisted of 2 ways, namely the test method and the questionnaire method. The test method is used to obtain fitness data and the questionnaire method is used to obtain student independence data. Following are the results of the data obtained from this study .

Table 1. Compare two variable

\begin{tabular}{|c|c|c|c|c|c|c|}
\hline \multirow[b]{2}{*}{ Source } & \multirow[b]{2}{*}{ Dependent variable } & \multicolumn{2}{|l|}{ Type III } & \multirow[b]{2}{*}{$\begin{array}{l}\text { Mean } \\
\text { Square }\end{array}$} & \multirow[b]{2}{*}{ F } & \multirow[b]{2}{*}{ Sig. } \\
\hline & & $\begin{array}{l}\text { Sum of } \\
\text { Squares }\end{array}$ & df & & & \\
\hline \multirow[t]{2}{*}{ Transportation } & Fitness & 146,787 & 2 & 73,393 & 21,914 &, 000 \\
\hline & Autonomy &, 175 & 2 &, 087 &, 890 & ,414 \\
\hline
\end{tabular}

Based on the table above, it can be concluded that the difference in fitness of students based on the transportation used is significant, this is indicated by a significance value of $0,000<0.05$ with an $F$ value of 21,914 . As for the independence variable students based on transportation is not significant, because it is indicated by a significance value of $0.414>0.05$ with an $\mathrm{F}$ value of 0.175 . Furthermore, to find out the extent of the differences in each dependent variable (independence and fitness), it is necessary to carry out a multicomparison test using the LSD method. The following results are displayed in the table:

Table 2. Multi Table Comparison with LSD

\begin{tabular}{|c|c|c|c|c|}
\hline \multirow{3}{*}{$\begin{array}{l}\text { Depandan } \\
\text { variabel }\end{array}$} & \multirow[b]{3}{*}{ Transportation (I) } & \multirow[b]{3}{*}{ Transportation (D) } & \multicolumn{2}{|l|}{ Mean } \\
\hline & & & Difference & Sig \\
\hline & & & $(1 \cdot \sqrt{)})$ & \\
\hline \multirow[t]{6}{*}{ Fitmess } & Ride a bicycla & $\begin{array}{l}\text { Delivered by } \\
\text { perants ridinga } \\
\text { motorcycla }\end{array}$ & 2,2419 &, 000 \\
\hline & & On foot & -2671 & 680 \\
\hline & \multirow{3}{*}{$\begin{array}{l}\text { Dalivered by } \\
\text { parents ridinga } \\
\text { motoncycla }\end{array}$} & Ride a bicycla & $-2,2419$ &, 000 \\
\hline & & $0 \mathrm{a}$ foot & $-2,5090$ &, 000 \\
\hline & & Ride a bicycle &, 2671 &, 680 \\
\hline & On foot & $\begin{array}{l}\text { Delivered by } \\
\text { perants ridinga } \\
\text { motorcycla }\end{array}$ & 2,5090 &, 000 \\
\hline \multirow[t]{6}{*}{ Autonomy } & Ride a bicycla & $\begin{array}{l}\text { Delivered by } \\
\text { pereats ridinga } \\
\text { motoncycla }\end{array}$ & -0570 &, 370 \\
\hline & & Oa foot & -1364 & 220 \\
\hline & Dalivered by & Ride a bicycla &, 0570 &, 370 \\
\hline & $\begin{array}{l}\text { parants ridinga } \\
\text { motoreycla }\end{array}$ & On foot &, 0794 &, 460 \\
\hline & & Ride a bicycle &, 1364 & 2220 \\
\hline & On foot & $\begin{array}{l}\text { Delivered by } \\
\text { pereats ridinga } \\
\text { motorcycla }\end{array}$ &, 0794 & 460 \\
\hline
\end{tabular}


Based on the above table, it can be concluded as follows:

1. Comparison of fitness of students who use transportation to ride their own bicycles accompanied by parents riding a motorcycle has a significance of $0,000<0.05$ then there is a significant difference with a mean difference of 2.2419 .

2. Comparison of fitness of students who use transportation to ride their own bicycle on foot has a significance of $0.680>0.05$ then there is no significant difference with a mean difference of -0.2671 .

3. Comparison of fitness of students who use transportation between parents riding on a motorcycle with a bicycle alone has a significance of $0,000<0.05$ then there is a significant difference with a mean difference of -2.2419 .

4. Comparison of fitness of students who use transportation between parents on a motorbike on foot has a significance of $0,000<0.05$ then there is a significant difference with a mean difference of -2.5090 .

5. Comparison of fitness of students who use walking transportation by riding their own bicycle has a significance of $0.680>0.05$ then there is no significant difference with a mean difference of 0.2671 .

6. Comparison of fitness of students who use walking transportation by parents transfered by motorbike has a significance of $0,000<0.05$ then there is no significant difference with a mean difference of 2.5090 .

7. The comparison of the independence of students who use transportation to ride their own bicycles with parents accompanied by motorbike has a significance of $0.370>$ 0.05 then there is no significant difference with a mean difference of -0.0570 .

8. Comparison of the independence of students who use transportation to ride their own bicycle on foot has a significance of $0.220>0.05$ then there is no significant difference with a mean difference of -0.1364

9. The comparison of the independence of students who use transportation delivered by parents riding a motorcycle by riding their own bicycle has a significance of $0.370>0.05$ then there is a significant difference with a mean difference of 0.0570 .

10. Comparison of fitness of students who use transportation between parents on a motorbike on foot has a significance of $0.460>0.05$ then there is no significant difference with a mean difference of - .0794.

11. The comparison of the independence of students who use walking transportation by bicycle alone has a significance of $0.220>0.05$ then there is no significant difference with a mean difference of 0.1264 .

12. The comparison of the independence of students who use walking transportation by parent transfered by motorcycle has a significance of $0.460>0.05$ then there is no significant difference with a mean difference of 0.0794 .

\section{Conclusion}

Based on the results of research that has been done, the following conclusions can be drawn:

1. Overall the difference in the variables of independence and fitness on transportation is significant, this is indicated by the significance value of $0,000<0.05$ with an $F$ value of 10.425 on Wilk's Lambda.

2. In the fitness variable on student transportation modes there is a significant difference which is indicated by the significance value of $0,000<0.05$ with an $F$ value of 21,914.

3. The independence variable of the student transportation mode is not significant, as indicated by the significance value of $0.414>0.05$ with an $F$ value of 0.175 . 
The results of the multivariate test of testing can be concluded that the overall test results of variables (independence and fitness) on transportation are significant, this is indicated by a significance value of $0,000<0.05$ with an $F$ value of 10.425 on Wilk's Lambda.

But the extent to which the differences in each variable still need to be analyzed further. Based on the results of the test differences between variables found that the difference in fitness of students based on the transportation used is significant, this is indicated by the significance value of $0,000<0.05$ with an $F$ value of 21,914 . The means of transportation used by students to go to and from school affect their fitness because they are caused by physical activities undertaken by students. The difference in physical activity of these students causes differences in student fitness as well. Students who go to school walk higher fitness than children who go to school on their own bicycles, and also higher than children who go to school accompanied by parents riding a motorcycle. Can be described with symbols on the level of fitness of students who walk $>$ cycling $>$ accompanied by parents riding a motorcycle $(\mathrm{J}>\mathrm{S}>\mathrm{O})$. This difference is caused by various physical activities carried out by students. For students who walk, of course, requires more physical physical activity compared to cycling and being driven on a motorcycle. How not, on foot, almost all members of the body move actively so that it requires a lot of energy compared to cycling where only a few members of the body are active, especially children who are escorted by parents on a motorcycle, they are completely inactive activities just sit there without requiring energy the big one. As mentioned by Baro, 2016.

A person's physical fitness is the ability to adapt and respond to physical activities. So the habits of children who walk are indirectly the body's ability to adapt to respond to physical activities undertaken so that the body is accustomed to doing strenuous physical activity which results in increased fitness itself. Likewise in children who are escorted by parents on motorbikes to school, he is only accustomed to responding and adapting to low physical activity so that the body responds to low energy requirements and low activity as well, this is the situation that causes less physical fitness can develop.

According to Maksum, 2018. Physical activity is one of the instruments to improve body fitness. In this case the physical activity of children in the form of a habit of biking or walking to school makes daily physical activities undertaken. Indirectly this activity resulted in an increase in their body fitness. Physical activity resulting from the use of transportation in the form of walking or cycling is higher than motorized transport.

At the level of independence, there is no significant difference in the transportation of students to school indicated a significance value of $0.414>0.05$ with an $\mathrm{F}$ value of 0.175 . This is because independence is not directly related to the level of physical activity of the child but rather to parenting. As mentioned by Ayllon et.al., 2019 that the attitude of parents in increasing the independence of their children is an important factor. In the case of transportation of students to school is an effort of parents to train the independence of children but these efforts are still not successful significantly, other efforts need to be made even better so that the independence of their children can develop properly.

There are several factors of independence, namely internal and external. Internal factors come from within, namely genes, birth order, age, gender and intelligence. While external factors are parenting, education system in schools, conditions of the surrounding community. In this case the internal factors are very influential on the development of children's independence. Although the choice of transportation mode does not affect the difference in children's independence, but going to school on foot or on a bicycle must still be done considering this mode of transportation can affect differences in children's fitness. 
Do not let the child is not independent and not fit just because the selection of transportation modes is not right.

Efforts to train children's independence by parents cannot only be from external factors or internal factors. Both must be balanced. However, internal factors are less able to be manipulated to influence the independence of children, but external factors that must be designed in such a way as to achieve the expected independence of children.

\section{References}

Abdurrahim and Hariadi.2018. Physical Fitness Level Students of SDN Tulungrejo 03 Highland Region Bumiaji District Batu City Academic Year 2018/2019. Indonesia Performance Journal. 2 (2), 68-73

Agustavian, Arys, M. I. and Hartati, S. C. Y. 2013. Difference Between Cycling and Walking to School on Students' Physical Fitness Level (Study of Class VII Students of Sempu 1 Public Middle School, Banyuwangi). Journal of Sports and Health Education . 1 (1), 125-131

Ayllón, Esther, Moyano, N., Lozano, A. And Cava, M. J.2019. Parents' Willingness and Perception of Children's Autonomy as Predictors of Greater Independent Mobility to School. International Journal of Environmental Research and Public Health n.16, 732; doi: 10.3390 / ijerph16050732.

Baro, Mantu and Sumit Kr Thapa. (2017). Physical Fitness and Wellness-Challenge in the 21st Century. International Journal of Physical Education, Fitness and Sports. 5 (1), $29-32$.

Esteban and cornejo., Et al .2014. Independent and Combined Influence of the Components of Physical Fitness on Academic Performance in Youth. The Journal of Pediatrics .162 (2), 306-312.

García, et al.2014. Physical Fitness Level and Its Relationship with Self-Concept in School Children. Psychology . 5, 2009-2017.

Irfansyah. 2020. The Duties and Functions Performance of Aceh Human Resources Improvement Institutions in Scholarship Study Program Implementation in Aceh Government. Britain International of Humanities and Social Sciences (BIoHS) Journal (2): 160-165.

Kek, Chiewing, GarcBengoechea, E., John, C. and Spence. (2019). The Relationship between Transport to School Habits and Physical Activity in the Sample of New Zealand Adolescents.Journal of Sport and Health Science.8. doi.org/10.1016/j.jshs.2019.02.006.

Maksum, and Ali.2018. Research Methodology in Sports. Second Edition. Surabaya: Unesa University Press.

Maksum and Ali.2018. Statistics in Sports. Surabaya: Unesa University Press.

Maksum and Ali .2018. Quality Sports for All. Sports Science Week, Surabaya.

Mar'at, Samsunuwiyati.2008. Developmental psychology. Bandung: Teen Rosdakarya.

Marlinawati, Salimo, H. and Murti, B.2017. Effect of Play Group and Biopsychosocial Factors on the Independence Development of Preschool Children in Surakarta. Journal of Maternal and Child Health . 2 (4), 284-296.

Mulyati and Martiastuti, K. 2018. The Relationship Between Family Function and Adolescent Autonomy in the Rural and Urban Areas. Journal of Family Sciences. 3 (1), 15-29.

Nanette, E., Kobel, S., Et al.2014. Parental Activity as Influence on Children BMI Percentiles and Physical Activity. Journal of Sports Science and Medicine. 13, 645-650.

Nazeer, Tahir, M., Rabia and Gill, S. A.2016. Impact of Fitness Awareness on Physical 
Fitness and Exercise Activities of Visitors in Public Parks. Sci.Int. (Lahore) . 28 (5), 99. 102.

Nosa, Septian, A. and Muhammad, F.2013. Survey of Physical Fitness Level at Lumajang Indonesian Football Association Players. Sports Achievements. 1 (1). 1-8.

Nuraflah, C. A. 2020. The Communication Strategy of Government in Bulu Cina Village towards Prosperous Village. Britain International of Humanities and Social Sciences (BIoHS) Journal (2): 374-380.

Ortega, et al 2008. Physical Fitness in Childhood and Adolescence: A Powerful Marker of Health. International Journal of Obesity .32, 1-11.

Palar, Chrisly, M., Wuling, D. and Ticoalu, S. H. R (2015). Benefits of Aerobic Exercise Against Human Physical Fitness. Journal of e-Biomedics (eBm). 3 (1), 316-321.

Perry, Tam, E., Hassevoort, L., Ruggiano, N. and Shtompel, N. (2015). Erikson's Applying Wisdom to Self-Management Practices of Older Adults: Findings from Two Field Studies. doi: 10.1177 / 0164027514527974.

Ryan, Richard, M., Deci, E., and Vansteenkiste, M.2015. Autonomy and Autonomy Disturbances in Self-Development and Psychopathology: Research on Motivation, Attachment, and Clinical Process. Cicchetti c09.tex V1. 1, 385-436.

Rui, Z., Yao, E. and Liu, Z.2017. Choice Travel Fashion School in Beijing China. Journal of Transport Geography. 62, 88-110.

Sa'diyah and Rika. 2017. The Importance of Practicing Children's Independence. Coordinates. 15 (1), 31-46.

Sastaman, B. andSon. 2015. Analysis of Physical Fitness Levels Between Students Walking and Cycling in Male Students Class Viii Madrasah Tsanawiyah Negeri 1 Pontianak. Journal of Physical Education , 4 (2), 170-181.

Satrio, U., Wahyu, M. and Wahyuni, E. S.2014. Comparison of Physical Fitness Levels between Cycling Students and Walking to School (Study of Grade VIII Students of SMP Negeri 2 Deket). Journal of Sports and Health Education. 2 (1), 223-226.

Septian, Zola, L., and Jarmiko, T.2018. Effect of Interval Training to VO2max Athletes Wrestling Sme Surabaya State University. Sports achievements . 3 (1), 1-18.

Setyaningsih, Puji and Yuliandi, R.2019. Comparison of Fitness Levels of Students Who Followed and Did Not Join Dance Studio Activities. Journal of Sports and Health Sciences. 8 (1), doi.org/10.36706/altius.v8i1.8238.

Sholihin, Moh and Wahyuni, E. S.2013. Comparison of Students' Physical Fitness Levels Based on Different Transportation to School Patterns (Study in Class VIII of SMP Negeri 3 Sampang). Journal of Sports and Health Education. 1 (2), 348-352.

Sugiyono. 2012. Qualitative and R\&D Quantitative Research Methods. Bandung: Alfabeta.

Suid., Syafrina, Alfiati and Tursinawati.2017. Analysis of Student Independence in the Learning Process in Class III Sd Negeri 1 Banda Aceh. Journal of Basic Charms . 1 (5), 70-81.

Sutrisno.2018. Multivariate Analysis of Variance (MANOVA) to Enrich Educational Research Results. Axiom . 9 (1), 37-53. 